DOI: 10.20472/IAC.2018.042.035

\title{
BAJRAWAN NUCHPRAYOOL
}

National Institute of Development Administration, Thailand

\section{LEGAL REFORM OF ASSET DECLARATION SYSTEM: A STRATEGY TO PREVENT AND COMBAT CORRUPTION IN THAILAND}

\begin{abstract}
:
Declaration of assets and liabilities by politicians and public officials can be a powerful tool to prevent and fight corruption. Politicians and public officials are obliged by the Organic Act on Counter Corruption B.E. 2542 to submit an account showing particulars of their assets and liabilities and to disclose such account to the public. It has been acknowledged that a number of the assets declaration reports have been left unverified by the National Anti-Corruption Commission (NACC), thus making the system ineffective. The purpose of this study is to examine, analyze, and compare the asset declaration systems in Thailand and in other countries, as well as the problems and obstacles in practice.

This study found that in order to improve the efficiency and effectiveness of the asset declaration system, NACC should make it compulsory for all types of public officials to submit an account showing particulars of their assets and liabilities but verify an account only when there are doubts about a submitted account or only for positions with high risk of conflict of interest. The deployment of information technology in the asset declaration system especially for the filing process and the verification process as well as linking the information from other government agencies and private organizations shall increase the efficacy of the system. The disclosure of account showing particulars of assets and liabilities should be required from everyone who is holding a political position and from every public official so that the general public will be able to examine the disclosed information. Finally improving the organizational structure of NACC to be in line with the asset verification system can increase the effectiveness of the system.
\end{abstract}

\section{Keywords:}

Declaration of assets and liabilities, National Anti-Corruption Commission, assets and liabilities

JEL Classification: K49, K10, K42 


\section{Introduction}

The Asset and Liabilities Declaration and Verification System for government officials has been in Thailand for more than 40 years. Since then, there has been a continuous improvement of the assets and liabilities verification system, which has tended to increase the strictness of the system. That is, in addition to examining the correctness and existence of assets and liabilities, it also focuses on the irregular changing of assets that leads to unusual wealth for persons holding political positions and government officials. This has resulted from a large number of corruption issues involving persons holding political positions and government officials in Thailand. It is also the result of examining the need to reform the system's structure based on the Constitution. However, it has been found that corruption issues still exist and have tended to continuously increase. According to the Corruption Perceptions Index 2017, Thailand is ranked 37 out of 100 (Transparency International, 2017), which suggests the seriousness of corruption issues in Thailand.

Initially, an examination of assets and liabilities was in the power and duty of the Office of the Commission of Counter Corruption, according to Counter Corruption Act 1975. The Act focused on the declaration of assets and liabilities of government officials, especially Prime Ministers, ministers, members of the House of Representatives, and senators, who are required to submit a declaration of assets and liabilities. However, law enforced at that time did not prescribe a means for revealing assets and liabilities data to the public or for the examination of the existence of assets and liabilities. That lack of a process of examination led to the defectiveness of the assets and liabilities examining system. Furthermore, the Office of the Commission of Counter Corruption is under Prime Minister's Office, which controlled by persons holding political positions; therefore, it was not truly independent of the political sector.

This defectiveness of the assets and liabilities examining system for persons holding political positions and government officials has led to the major reformation of the assets and liabilities examining system. The Constitution of Kingdom of Thailand 1977 (B.E. 2540) prescribed the establishment of the National Anti-Corruption Commission as an independent administration agency. It also prescribed the persons holding political positions who have duties to submit an account declaring assets and liabilities. These persons include the Prime Minister, ministers, members of the House of Representatives, senators, other political officials, local administrators, and members of the local councils. Moreover, the Organic Act on Anti-Corruption 1999 prescribed rules requiring these individuals to include the assets and liabilities accounts of their spouses and their minor children in their statements. The Constitution of Kingdom of Thailand 2007 (B.E. 2550) also maintains this concept; however, multiple problems were still detected in the assets and liabilities examining system (Nuchprayool B.,2016). For instance: 
1. The Act prescribes that only persons holding high-level political positions have duties to declare assets and liabilities, which leads to problems examining the existence of assets and liabilities for those holding state official positions at other levels that might also invite corruption.

2. Some types of declaring lists, such as those for valuable assets like amulets, jewelries, accessories, art works, etc., require presenting photos with prices as evaluated by the assets' owners. This leads to issues about uncertain prices. Moreover, the National AntiCorruption Commission does not have an expert on staff with expertise in examining valuable assets. In the process, such as in the case of examining an amulet, officials cannot evaluate the price themselves and when the expert in evaluating amulet price does an evaluation, the price is different from that declared by the official. Therefore, the actual prices of these assets are uncertain.

3. For the submission of asset and liability accounts, the law prescribes submitting every page of account documents and their copies, as well as providing details of additional documents of assets and liabilities for the account. Although there has been a development of an electronic submission program, it has not been adopted extensively in practice. The persons who have the duty to submit accounts still have to submit physical documents, which causes a problem searching the evidence and creates a burden for officials in the process of filing documents. (Nuchprayool, B. \& Kulsudjarit, A., 2018)

4. Examinations sometimes occur too late during the changing of positions of persons who have duties to submit assets and liabilities accounts, which leads to a large number of backlogs for examining more than 60,000 accounts.

5. The Organic Act on Anti-Corruption does not prescribe rules regarding the timeframe for examining the correctness and existence of assets. In practice, there is no time clause enforced by law. However, there might be the force of policy or command, which sometimes leads to quantitative achievement rather than qualitative achievement and numerous pending assets and liabilities accounts to delay. The delay and inefficiency of an examination affects the general efficacy of the National Anti-Corruption Commission's examining process and has a negative effect on persons who submit accounts due to unknown examination results. (Nuchprayool B.,2017).

6. The act prescribes rule only for the declaration of assets and liabilities of persons holding high-level political positions, including the Prime Minister, ministers, members of the House of Representatives, and senators. The study shows that the declaration of assets and liabilities is a significant measure that allows the citizen sector to participate in the examining process of persons in the administrative and legislative sector. Citizen can also check and notify officials about whether or not their assets and liabilities accounts are correct. However, the usefulness of the type of data to be disclosed should be considered. Considering the objective of disclosing assets and liabilities data can do this. Moreover, 
the Act does not prescribe rules to disclose assets and liabilities data for local politicians and state officials, which results in citizens lacking the opportunity to examine and participate in informing additional data that might be useful for examination.

\section{Asset and Liabilities Declaration and Verification System of Political Positions in Thailand}

The issues mentioned above raises the problem of developing an effective assets and liabilities system in Thailand. The Constitution of Kingdom of Thailand 2017 (B.E. 2560) and The Organic Act on Anti-Corruption 2018, which will be enacted on July 21, 2018, prescribes rules for the submission and examination of assets and liabilities in Chapter 5 , "Examination of Assets and Liabilities." ${ }^{1}$ The main points are described below. (Sukboon W, 2017)

1. The submission and examination of assets and liabilities accounts.

The law divides persons who have the duty to submit an account into two groups. Group 1 is people holding political positions and their spouses or their husbands/wives, as well as their minor children. This groups consists of (1) persons holding political positions; (2) constitutional court judges; (3) persons holding positions in an independent agency; (4) judicial service officials working in the Courts of Justice; (5) administrative court judicial service officials in the administrative courts and those who hold a position of chief judge in first instance court and higher position; (6) prosecutor service officials who hold the position of attorney general or higher; (7) persons holding high-level positions; (8) other positions based on other laws that prescribe duties to submit assets and liabilities accounts; and (9) local administrators and deputy local administrators and members of local councils defined under the Organic Act on Anti-Corruption. ${ }^{2}$ These persons will disclose the results of examination to the public. The new law prescribes an additional imposition to cover couples that marry to manipulate assets, which was a problem that occurred in the legal system in 1999.

For Group 2, the new law prescribes rules for state officials who have salary and permanent positions to submit assets and liabilities accounts to government offices and state enterprises or state agencies under which they serve. ${ }^{3}$ In summary, the law aims to impose duties to submit assets and liabilities account on persons who hold state power or who are appointed by law to a position of government authority, including a person, a commission, or a private citizen who is appointed to hold administrative power. They can submit their accounts secretly to their office, which is a measure written into Chapter 7 to prevent and suppress corruption. This is an additional measure in the 1999 Act.

\footnotetext{
${ }^{1}$ Articles 102-114 of the Organic Act on Anti-Corruption 2018

2 Article 102 of the Organic Act on Anti-Corruption 2018

${ }^{3}$ Article 130 of the Organic Act on Anti-Corruption 2018
} 


\section{The declaration of assets and liabilities account.}

The Organic Act on Anti-Corruption 2018 prescribes duties on the National Anti-Corruption Commission to declare assets and liabilities accounts, the location of immovable property, and additional documents within 30 days as from the due date for persons holding political positions, their spouses and minor children (in the case of Prime Ministers), ministers, members of the House of Representatives and senators, constitutional court judges, persons holding positions in independent agencies, persons holding high-level positions, local administrators, deputy local administrators, and members of local councils. ${ }^{4}$ This is an improvement on the declaration of assets and liabilities accounts over the 1999 Act, which were limited to persons holding political positions only. The reason for an expansion of the law on declarations was to decrease the tendency toward corruption by persons holding other positions and to allow citizens to participate in assets and liabilities examining process, especially in the case of local-administrator commissions and members of local councils, which have a close relationship with citizens in a local area.

Moreover, the law prescribes rules regarding the protection of personal information for persons holding positions if doing so would cause dangerousness to the owner of information. The National Anti-Corruption Commission might consider deleting or cutting out personal information (such as location, etc.) as long as it does not disclose information before a declaration to the general public.

When an examination of assets and liabilities accounts has been done, The National AntiCorruption Commission has a duty to declare the results of the examination to public and notify them of whether or not the result is usual.

3. The examination of assets and liabilities ${ }^{5}$

The Organic Act on Anti-Corruption 2018 prescribes that the National Anti-Corruption Commission examine the correctness and existence of assets and liabilities accounts for nine categories of persons holding positions mentioned above by examining every account. For state officials whom the law requires to submit assets and liabilities accounts, the National Anti-Corruption Commission will call for an examination in cases of suspicion of corruption. However, the requirement to examine every account is the main reason for the delay of the examining process. This is because there are a large number of accounts pending examination and it is hard to examine them in detail. Sometimes, the examination is not finished by the time of persons changing positions who have the duty to submit assets and liabilities accounts.

\section{Offences and Penalties}

\footnotetext{
${ }^{4}$ Article 106 of the Organic Act on Anti-Corruption 2018

${ }^{5}$ Article 110 of the Organic Act on Anti-Corruption 2018
} 
In cases where persons who have duties to submit assets and liabilities accounts intend to avoid submitting their accounts or intend to submit a fake account or conceal facts that should be notified, and when there is a circumstance believed to show an intention to conceal a source of assets and liabilities, the issue can be brought to the Criminal Division for Persons Holding Political Position of The Supreme Court, The Central Criminal Court for Corruption and Misconduct Cases for adjudication. Findings of guilty in such cases are punishable by imprisonment for not more than six months and fines of not more of ten thousand Bath, or both imprisonment and fine. Moreover, in cases of the discovery of unusual wealth, the law prescribes that the commission investigate in order to request that the assets to become publically owned. ${ }^{6}$

\section{The Analysis and Recommendations for the improvement of examination of assets and liabilities account.}

This study examining Thailand's assets and liabilities system found that Thailand has attempted to prevent and suppress corruption by bringing in the assets and liabilities examining system as a tool to solve corruption issues. However, when considering the economic principles behind the examination of assets and liabilities together with the legal principles, there are some considerations about the efficiency of examining systems from an economic perspective: "is it true that the system can create transparency and prevent corruption, as well as, a conflict of interest of state official or not?" This study found that there are measures and mechanisms in The Organic Act on Anti-Corruption, B.E 2561, including the following

Firstly, although the law has added mechanisms regarding submitting the assets of state officials, there is still a focus on examining the accounts of nine types of persons who hold high-level positions. Examining every account without classifying an order of necessary or order of risk causes a delay in examinations and a loss of valuable limited resources. In sum, an examining system that examines every account aims to focus on the quantity of examinations. If the commission lacks resources for the examination process, it will affect the quality of examination.

To address this problem, the researcher suggests adjusting the method or format of the examination. In the previous way that the commission examined the correctness and existence of assets and liabilities, every account was submitted not to examine every account but to rearrange the risk order of persons holding positions, on whom the law imposes duties to submit accounts into categories. The most risky categories require the examination of the correctness and existence of listed assets and liabilities in every accounts and regularly checking for unusual changes. The commission also needs to focus on qualitative examination-that is, examinations that are done in more detail.

${ }^{6}$ Article 114 of the Organic Act on Anti-Corruption 2018 
Secondly, the current law does not prescribe rules about timeframes for examining the correctness and existence of assets. In practice, there is no time clause; however, the process might be enforced by a policy or a commander. Sometimes, this leads to quantitative achievement rather than qualitative achievement and numerous pending examinations of assets and liability accounts. Delays and inefficiencies in examinations affect the general efficacy of the examining process of the National Anti-Corruption Commission and have negative effects on persons who submit accounts. To address this issue, the researcher proposes imposing a timeframe for the examination process.

Thirdly, the present adoption of technology for assisting in the process of submission and examination assets and liabilities by the National Anti-Corruption Commission is at the initiative stage. Currently, persons who have duties to submit accounts still have to submit a physical document, which is a main cause of examination delays and burdens on the commission. Furthermore, not storing data via technology or storing data via inefficient technology causes difficulty connecting data and assets during the examination. In addition to these problems, it was found that the commission lacks a data connection network with financial agencies and other state agencies, such as commercial banks, investment management companies, stock exchanges, and state registry agencies. In the process of the examination, the commission has to request data case by case, which causes delays and backlogs. To address this issue, the researcher proposes improving the examination by adopting technology immediately and quickly to create a database that is connected with other agencies. However, it is important to remain aware of the safety of personal information.

The adoption of technology for these examinations can increase their efficiency and improve their results, especially in the process of examining the correctness and existence of reported assets and liabilities accounts as well as unusual changes. However, the essential changes that will lead to an improvement of the system, including the of technology, are the availability of administrative personnel, the inclusion of officials from every sector, and training in the use of technology, which will, together, ultimately improve the results of the assets and liabilities examining system.

\section{References}

Bowornwathana, B., \& Wescott, C. G. (2008). Comparative Governance Reform in Asia: Democrary, Corruption, and Government Trust. Bingley, UK.: Emerald Group Publishing.

Nuchprayool, B. (2017). Proposal for improving the effectiveness and efficiency of The Asset and Liabilities Declaration and Verification System. Bangkok: NACC.

Nuchprayool, B. \& Kulsudjarit, A. (2018). Implementing Information Systems for Asset Collecting and Analysis System to Enhance the efficiency and effectiveness of The Asset and Liabilities Declaration and Verification System. NACC Journal, 2018, Vol.11 No.1. 
OECD. (2013). Specialised Anti-Corruption Institutions Review of Models: Second Edition (Vol. Second Edition). Paris: OECD.

Quah, J. S. (2011). Curbing Corruption in Asian Countries: An Impossible Dream? Bingley: Emerald Group Publishing.

Rose-Ackerman, S. (1999). Corruption and Government: Causes, Consequences, and Reform. Cambridge: Cambridge University Press. SEA-PAC. (2015).

SEA-PAC. Retrieved from South East Asia Parties Against Corruption: http://www.sea-pac.org/? $p=5102$

Stapenhurst, R., Johnston, N., \& Pelizzo, R. (2006). The Role of Parliament in Curbing Corruption. New York: World Bank Publications.

Sukboon, W. (2017). Assets Inspection of National Anti-corruption Commission and Constitution of Kingdom of Thailand B.E. 2560. NACC Journal, 2017, Vol.10 No.2.

Tan, A. T. (2013). East and South-East Asia: International Relations and Security Perspectives. Iondon: Routledge.

Transparency International. (2017). Corruption Perceptions Index 2017. Retrieved from Tranaparency International:https://www.transparency.org/news/feature/corruption_perceptions_index_2017

Zhang, Y., \& Lavena, C. (2015). Government Anti-Corruption Strategies: A Cross-Cultural Perspective. Singapore: CRC Press. 